\title{
COMPREENDENDO BAKHTIN ATRAVÉS DO SERIADO MERLÍ
}

\section{UNDERSTANDING BAKHTIN THROUGH THE MERLÍ SERIES}

\author{
COMPRENDENDO A BAJITÍN A TRAVÉS DE LA SERIE MERLÍ
}

Joélica Pereira de Lima ${ }^{1}$

Leonardo Gomes da Silva ${ }^{2}$

Fábio Marques de Souza ${ }^{3}$

1. Mestranda do Programa de Pós-Graduação em Formação de Professores (UEPB). Especialista em Fundamentos da Educação (UEPB). Graduada em Licenciatura Plena em Geografia (UEPB). Professora efetiva da Rede Pública Estadual da Paraíba, desde 2013. Leciona desde 2008. Membro dos Grupos de Pesquisa: Ensino de Geografia, UEPB/DGP/CNPq; O círculo de Bakhtin em diálogo, UEPB/DGP/CNPq. Cuité-PB, Brasil. Contato: joelicalima@gmail.com

2. Graduando em Filosofia (UNIASSELVI). Licenciado em Química (UFCG). Técnico em Segurança Pública na Rede Pública Estadual da Paraíba (PMPB), desde 2014. Membro do Grupo de Pesquisa: O círculo de Bakhtin em diálogo, UEPB/DGP/CNPq. Cuité-PB, Brasil. Contato: leosilvact122@gmail.com

3. Professor pesquisador no Programa de Pós-graduação em Formação de Professores (UEPB). Professor no Departamento de Letras e Artes da UEPB Mestre (UNESP) e Doutor (USP) em Educação, com estágio de Pós-doutorado em Educação Contemporânea (UFPE). Coordenador do Grupo de Pesquisa: O círculo de Bakhtin em diálogo, UEPB/DGP/CNPq. Campina Grande-PB, Brasil. Contato: fabiohispanista@gmail.com

RESUMO: Há diversos textos e estudos sobre vida e obra de Mikhail Bakhtin, mas, para quem inicia sua trajetória neste universo, nem sempre é possível achar algo que esclareça as dúvidas sobre os principais conceitos de forma direta. Propomos aqui, não apenas trazê-los de forma clara $\mathrm{e}$ objetiva, mas relacioná-los com a série televisiva Merlí, disponível na Netflix, de forma lúdica. Por meio das aulas irreverentes de um professor nada convencional, o leitor poderá acompanhar o texto juntamente com o episódio abordado e relacionar o conteúdo versado com sua própria vivência. Dividimos cada subtópico em um conceito bakhtiniano e um trecho do recurso imagético que pode ser verificado, para que as explanações fiquem o mais claro possível. Assim sendo, ao assistir, o leitor estará não apenas estudando e tirando dúvidas, como também trazendo o conhecimento para suas próprias experiências e inteirando-se mais de Bakhtin.

Palavras-chave: Mikhail Bakhtin. Série televisiva. Recurso imagético. Fundamentos bakhtinianos.

\begin{abstract}
There are several texts and studies on the life and work of Mikhail Bakhtin, but, for those who start their journey in this universe, it is not always possible to find something that directly clarifies doubts about the main concepts. We propose here, not only to bring them in a clear and objective way, but to relate them to the television series Merlí, available on Netflix, in a playful way. Through the irreverent lessons of an unconventional teacher, the reader will be able to follow the text together with the episode covered and relate the content with his own experience. We divided each subtopic into a Bakhtinian concept and an excerpt from the imagery that can be verified, so that the explanations are as clear as possible. So, when watching, the reader will not only be studying and clearing doubts, but also bringing knowledge to his own experiences and learning more about Bakhtin.
\end{abstract}

Keywords: Mikhail Bakhtin. TV series. Imaging resource. Bakhtinian fundamentals.
RESUMEN: Existen varios textos y estudios sobre la vida y obra de Mikhail Bakhtin, pero, para quienes inician su andadura en este universo, no siempre es posible encontrar algo que aclare directamente dudas sobre los conceptos principales. Te proponemos aquí, no solo traerlos de forma clara y objetiva, sino relacionarlos con la serie de televisión Merlí, disponible en Netflix, de forma lúdica. A través de las lecciones irreverentes de un profesor poco convencional, el lector podrá seguir el texto junto con el episodio cubierto y relacionar el contenido con su propia experiencia. Dividimos cada subtema en un concepto bakhtiniano y un extracto de las imágenes que se pueden verificar, para que las explicaciones sean lo más claras posible. Entonces, al mirar, el lector no solo estará estudiando y despejando dudas, sino también aportando conocimiento a sus propias experiencias y aprendiendo más sobre Bakhtin.

Palabras-clave Mikhail Bakhtin. Series de Televisión. Recurso de imágenes. Fundamentos bakhtinianos. 


\section{Introdução}

Todos já tivemos em nossa vida acadêmica aquele professor que marcou, seja por seu jeito descontraído e brincalhão, seja por uma metodologia diferente dos outros professores, algo que ficou em nossas memórias, como uma aula diferente ou um passeio (aula de campo), no qual o conteúdo didático ganhou mais leveza e, mesmo se não lembrar o ano, o nome daquele docente certamente virá a mente. Esta é uma síntese da personagem central Merlí Bergeron (Francesc Orella) ${ }^{1}$ da série espanhola Merlí, disponível na Netflix ${ }^{2}$, um professor de filosofia nada convencional.

Dividida em duas temporadas de treze episódios e a terceira com catorze, a série retrata não somente a vida do educador, dentro e fora da escola, bem como todos os conflitos e dilemas enfrentados pelos alunos da turma e suas famílias, construindo uma trama totalmente intrigante. Neste sentido, o objeto central deste construto é discutir sobre conceitos desenvolvidos por Bakhtin por meio série espanhola Merlí, disponível na Netflix.

Mikhail Bakhtin (M. B.) foi um filósofo russo que se dedicou a estudar os discursos cotidianos, como também criou conceitos para descrevê-los e os categorizou. Para este pensador, todo discurso, denominado por ele de enunciado, é envolto em ideologias que vêm sempre à tona por meio do dialogismo. Bakhtin, segundo matéria do site Nova Escola: "Foi um dos mais destacados pensadores de uma rede de profissionais preocupados com as formas de estudar linguagem, literatura e arte, que incluía o linguista Valentin Voloshinov (1895-1936) e o teórico literário Pavel Medvedev (1891-1938)”3, componentes do grupo de acadêmicos do 'Círculo de Bakhtin'.

No decorrer de sua vida, M. B. não publicou muitos livros, sendo algumas de suas obras: Problemas da Poética de Dostoiévski, O método formal nos estudos literários, Discurso na vida e discurso na arte, Freudismo: uma crítica marxista, Marxismo e filosofia da linguagem. Outras obras assinadas por colegas do Círculo de Bakhtin geram dúvidas quanto aos seus verdadeiros autores, sendo que em algumas traduções se atribui apenas a Bakhtin, e em outras obras recebem dupla autoria, como Bakhtin/Volochinov.

Como frisa Fiorin (2006), no decorrer do regime stalinista, Bakhtin foi condenado ao exílio na cidade de Kustanai, localizada na fronteira do Cazaquistão com a Sibéria. Alguns estudiosos afirmam que esse exílio foi proveniente de sua relação com a Igreja Ortodoxa. A intenção foi bani-lo para um campo de concentração, só que, em virtude de sua saúde debilitada, a condenação foi convertida em exílio. Em 1940, apresentou sua tese de doutorado, porém apenas no ano de 1946 veio a defendê-la, devido à guerra. Em

\footnotetext{
${ }^{1}$ Elenco do seriado disponível em: https://universoestendido.com.br/listas/merli-curiosidades-personagens-temporadas-e-mais/. Acesso: 18/08/2020 às 21:04.

2 Plataforma de streaming, pacote pago com acesso a filmes, séries, animações.

${ }^{3}$ Site Nova Escola. Disponível: https://novaescola.org.br/conteudo/1621/mikhail-bakhtin-o-filosofo-do-dialogo. Acesso em: $16 / 08 / 2020$ às 14:43.
} 
meio a muitas turbulências, o comitê negou-lhe o título de doutor, em 1952. Porém, em 1965, o texto foi publicado, dando-lhe renome mundial. Sua tese, intitulada "Rabelais e a cultura popular", causou grande polêmica na época, tornando-o famoso:

Bakhtin teve uma vida absolutamente comum, uma carreira apagada. Ele nunca teve apego a cargos e posições, nunca teve interesse pela fama e pelo prestígio. Sua trajetória foi marcada pelo ostracismo, pelo exílio e pela marginalidade dos círculos acadêmicos mais prestigiados. Teve, no entanto, ao longo de sua vida, uma intensa atividade de reflexão e escrita, que fez dele um dos grandes pensadores do século XX (FIORIN, 2006, p. 11).

Para melhor organizar nossa argumentação, dividimos o artigo em três seções. Na primeira, definimos o objeto de análise e descremos o método que nos direciono (crítico-dialético), além disso apresentamos a estrutura que desenvolvemos para análise do objeto. Em seguida, exibimos os resultados e discussões, no tópico intitulado 'Conceitos bakhtinianos presentes no seriado Merlí'. Dividimos esta seção em subtópicos específicos, referindo-se aos conceitos aplicados na análise. Assim temos: Enunciado, Dialogismo, Alteridade, Polifonia, Carnavalesco, Discurso Centrífugo e Centrípeto, Cronotopo, Exotopia, Memória do Passado e Refração.

Por fim, realizamos nossas considerações. Ao estabelecermos uma comparação entre cenas do audiovisual e o universo bakhtiniano, consideramos que seus conceitos são aplicáveis não somente na área de linguagens, mas tem muito a contribuir para diversos campos de estudo, como o científico, filosófico, artístico, educacional e geográfico. Embora apresentamos as concepções separadamente, compreendemos que sua complexidade se dá no processo de articulações entre elas.

\section{Metodologia}

Como direcionamento metodológico, seguimos a racionalidade crítico-dialética, tendo como objeto o episódio 11, da $2^{\mathrm{a}}$ temporada, intitulada Zizek, com pouco mais de 45 minutos de duração. O capítulo gira em torno de dois núcleos principais: Oksana/Gerard e Marc/Lídia. De acordo com Martins (1994, p.24), o método crítico-dialético considera a concepção dinâmica da realidade, buscando a "inter-relação do todo com as partes e vice-versa, da tese com a antítese", de modo que sua validade científica se dá no processo de correlações entre teorias e objeto.

Com esta direção, desenvolvemos uma análise do discurso do seriado, interconectando conceitos bakhtinianos à sua linguagem imagética. Para tanto, respaldamo-nos em estudiosos como Fiorin (2006), Souza e Di Camargo (2020a, 2020b), Souza e Soares (2020), Di Camargo (2019), Moretto, Silva e Wittke (2019), Faraco (2009), Fiorin (2006), entre outros. Ao relacionarmos com a série, buscamos exemplificar como os conceito bakhtinianos são empregáveis em nosso cotidiano. 
Cada conceito bakhtiniano é estudado aqui de forma isolada, constituindo os subtópicos do desenvolvimento. Escolhemos esta estruturação porque consideramos ser uma forma mais clara e fácil de apresentação das formulações do autor àqueles que estão dando os primeiros passos. Mas compreendemos que os discursos são formados conexões e inter-relações entre estes conceitos.

\section{Conceitos bakhtinianos presentes no seriado Merlí}

A linguagem imagética da sétima arte está cada vez mais presente em nossa vida, veiculada por meio das mais variadas plataformas de comunicação e interação, seja na televisão, cinema, ou por meio das mídias locativas, estamos nos habituando às formas, telas, efeitos, movimentos de câmaras e incidência de luz que compõem produtos audiovisuais. De acordo com Souza e Soares (2020, p. 22), "além de representar a vida, a arte cinematográfica dá forma às inquietações e desejos mais íntimos da alma humana”, afinal, tais produções cooperam para a construção de sentidos sociais.

Na contemporaneidade, invadidos por informações que perdem o caráter de novidade em instantes. Com observa Di Camargo (2020a, p. 34-35):

\footnotetext{
Uma das características da cultura contemporânea e da cultura de massas é a grande presença das imagens. [...] O crescimento da importância das imagens no mundo globalizado em relação às letras já é fato consumado. [...] Desde as tradicionais artes plásticas, passando pela fotografia, pelo cinema, pela TV e chegando à Internet, o homem tem utilizado diversos recursos para se comunicar através da imagem.
}

É na tela que assistimos reproduções de anseios e angústias, desejos e fantasias. Se nos faltam coragem para algo, entregamo-nos plenamente ao fabuloso da tela. As imagens prendem nosso imaginário e permitem que projetemos uma vida ficcional e/ou real, um mundo de sonhos ainda acordado. Essa "linguagem é constitutiva de sujeitos, de temporalidades, e, por conseguinte, olhando-se para a linguagem, vemos a sociedade que acerca" (DI CAMARGO, 2020a, p. 17).

Para entendermos esta sociedade audiovisual precisamos nos depreender da(s) dimensão(ões) espaço-tempo em que ocorrem as situações, e também buscar a lógica própria das personagens que compõem a esfera social representada. "Para Mikhail Bakhtin, essas esferas de acontecimentos - ou diríamos nós, mais tecnicamente: esses modos de trabalhar a matéria audiovisual - podem ser chamados de gêneros" (Ibid., p. 30).

E é com o gênero "série televisiva" que trazemos essa proposta de dialogizar com Bakhtin. Elencamos abaixo alguns dos conceitos que já tivemos contato por meio de estudos e pesquisas e expomos traços e pontos da série Merlí para exemplificar aquilo que venhamos a expor referente ao objeto que escolhemos para analisar: o episódio 11, da $2^{\text {a }}$ temporada, intitulada Zizek, com pouco mais de 45 minutos de duração. 
O capítulo gira em torno de dois núcleos principais: Oksana/Gerard e Marc/Lídia. O conflito entre Oksana (Laia Manzanares) e Gerard (Marcos Franz), ocorre por aquela ser mãe solteira e este por não aceitar muito bem que a namorada tenha filho. Quanto a Lídia (Anna Barrachina), separada e com dois filhos, trabalha no turno noturno e sai para se divertir durante o dia, deixando o filho caçula Pau (León Martínez) aos cuidados do mais velho, Mar (Adrián Grösser), que não aceita a ausência da mãe.

Outros acontecimentos também são retratados, como a relação entre a personagem principal e seu filho Bruno (David Solans), como veremos no decorrer de nossa análise, que começa com a descrição do enunciado.

\section{Enunciado}

Iniciemos nossos apontamentos por essa categoria indicada por Bakhtin. O ser vivo é dotado da capacidade de se comunicar, um gato ou um cachorro certamente fará ser notado caso esteja com fome ou com outra necessidade. Porém, ao ser humano cabe o desenvolvimento do processo comunicativo no qual um interlocutor se fazer entender por meio da organização da linguagem - falada/sonora, visual ou gestual - em um enunciado, de modo a provocar em outro uma reação; ou seja, a produção de outro enunciado, ainda que este seja apenas o silêncio. Por meio deste processo de produção enunciativa ocorre a troca de informações que caracteriza a comunicação social.

O enunciado, todavia, não se limita apenas ao discurso que o indivíduo externa. Enunciar não se restringe ao que é dito, é um pouco mais complexo no sentido de que o que se "fala" tem um sentido para quem o transmite, mas pode ser diferente para quem o capta, podendo ter interpretações diferentes: “[ [...] a maioria absoluta das opiniões dos indivíduos é social. [...] todo enunciado se dirige não somente a um destinatário imediato" (FIORIN, 2006, p. 27). Assim, o interlocutor pode enunciar algo, mas seu destinatário pode receber a mensagem e interpretá-la de outra forma, segundo suas próprias percepções, experiências (individuais e coletivas) e cognições que representam e são representados por sua linguagem.

\footnotetext{
Bakhtin/Volochinov consideram a linguagem em seus aspectos sócio-históricos culturais e movimentada por sujeitos. Os enunciados não são vistos como entidades abstratas, separados das condições de produção, mas como acontecimentos determinados por suas condições contextuais de produção/recepção (SOUZA; DI CAMARGO, 2019, p. 37).
}

Isto implica que cada indivíduo, em sua existência, tem uma forma de pensar e, consequentemente, de interpretar as mensagens que lhes são transmitidas: "Nossos enunciados emergem - como respostas ativas que são no diálogo social - da multidão das vozes interiorizadas. Eles são, assim, heterogêneos" (FARACO, 2009, p. 85). Esta concepção também está imersa naquilo que Fiorin (estudioso de Bakhtin) categoriza como estilo: 
A imagem que o enunciador faz de seu interlocutor tem um acabamento, dado por um estilo. Por isso, o estilo também pode ser determinado pelo parceiro da comunicação. Assim, é diferente fazer um enunciado dirigido a um amigo ou a um desconhecido, a uma autoridade ou a um colega de trabalho, a uma criança ou a um adulto (FIORIN, 2006, p. 48).

No início do episódio (Figura 1), Merlí coloca os alunos para limpar a sala de aula, para em seguida jogar o lixo todo sobre a mesa. Este enunciado foi uma forma do professor explicar e ilustrar o conteúdo, mas a forma como os alunos receberam tal enunciado foi de frustração, uma vez que eles tiveram grande trabalho com a limpeza da classe. A intenção do enunciado foi uma, a forma como foi recebida foi outra, mostrando que nem sempre o que se quer dizer será interpretado como se pretendia.

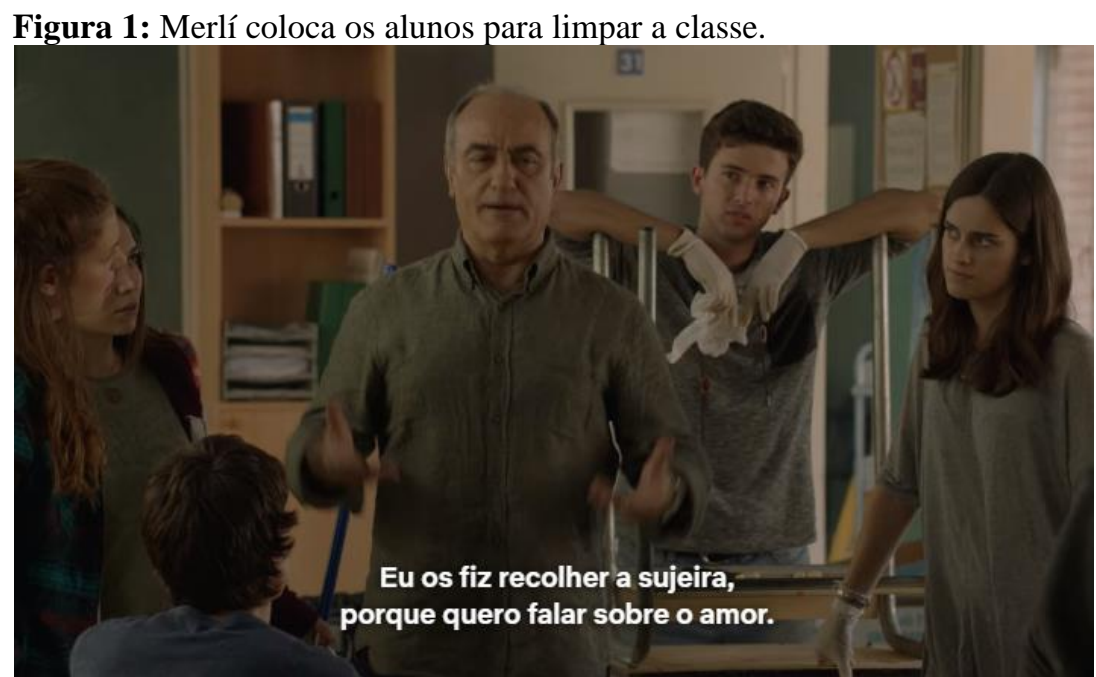

Fonte: Netflix, 2020

Podemos perceber esta categoria em todo o episódio, pois as personagens mantêm diálogos, trocando enunciados entre si, ora concordando com o enunciador, ora refutando, questionando, criticando, dialogizando. Conforme Souza e Di Camargo (2019, p. 39): “Assim, num filme, a palavra escolhida está em consonância com a empatia, com a concordância ou discordância de seu auditório, com sua relação ao seu objeto do enunciado".

Enunciar, então, não se resume ao diálogo em si, mas na externalização da mensagem e nas interpretações contidas nele por seus destinatários/receptores. Ao dialogarmos, cada indivíduo externaliza um enunciado que será recebido pelo destinatário.

Mas, se cada pessoa tem sua forma de interpretação, como se fazer entender? Para isso, o enunciado requer uma resposta, concordância ou refutação, visto ser uma "expressão de uma consciência individual, descolada da realidade social, uma vez que ela é formada pela incorporação das vozes sociais em circulação na sociedade" (FIORIN, 2006, p. 58). Apenas com a resposta que se chega ao dialogismo, uma espécie de entendimento entre as partes, o que discutiremos a seguir. 


\section{Dialogismo}

Se o enunciado é a forma como externalizamos a mensagem ao receptor, o dialogismo é a interação entre as partes, a comunicação e troca de enunciados. "O dialogismo são as relações de sentido que se estabelecem entre dois enunciados [...] todo enunciado é dialógico [...] dialogismo é o modo de funcionamento real da linguagem" (FIORIN, 2006, p. 19-24).

Esse dialogismo entre os participantes na troca de enunciados é o eixo norteador dos pensamentos de Bakhtin: "O diálogo é a base de toda a filosofia da linguagem do Círculo de Bakhtin [...] não é apenas uma ferramenta de análise e sim a relação entre o que se observa e o observador em si" (SOUZA; DI CAMARGO, 2019, p. 19).

O dialogismo pode ser explícito, de fácil entendimento e claramente visível (como por exemplo, quando um professor escreve no quadro “atividade para próxima aula: página 32”, é óbvio ao aluno que aquele exercício deve ser realizado e trazido na aula seguinte). Também pode estar implicitamente envolto no enunciado (dialogismo constitutivo), e carecendo da interpretação dialógica do destinatário. Por exemplo, quando uma criança faz birra em um estabelecimento público e a mãe diz: "em casa conversamos". Este prelúdio antecipa que haverá uma bronca ou castigo, mas a mensagem está nas entrelinhas.

\footnotetext{
Além do dialogismo constitutivo, que não se mostra no fio do discurso, há um outro que se mostra. Trata-se da incorporação pelo enunciador da voz ou das vozes de outro (s) no enunciado. Nesse caso, o dialogismo é uma forma composicional. São maneiras externas e visíveis de mostrar outras vozes no discurso. Isso é o que Bakhtin chama concepção estreita de dialogismo (FIORIN, 2006, p. $32-33)$.
}

Neste contexto, verificamos que todo enunciado parte para um receptor, é interpretado e voltará para o transmissor, gerando o dialogismo - troca de enunciados e, por conseguinte, de interpretações. "Dois é a base de todo o pensamento bakhtiniano. Eu e o outro. E daí parta-se para o social" (SOUZA; DI CAMARGO, 2019, p. 18), assim temos os possíveis dialogismos, como representamos na Figura 2.

Figura 2: Relações no dialogismo.

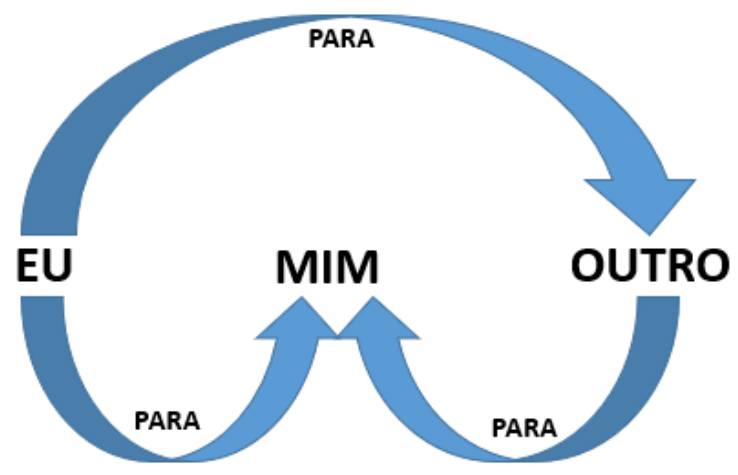

Fonte: Leonardo e Joélica, 2020 
O "eu para mim” se dá quando temos um dialogismo interno, autorreflexões e a percepção do que me cerca. O "eu para o outro" é a externalização da minha compreensão do que o outro enunciou, ela é emanada pela minha própria percepção e carregada do meu dialogismo com o mundo. O "outro para mim" é o retorno do que foi enunciado, a resposta dialógica do que ele compreendeu e que carece (ou não) de uma resposta minha em seguida. A Figura 3, representa este movimento.

Figura 3: Aula sobre Zizek.

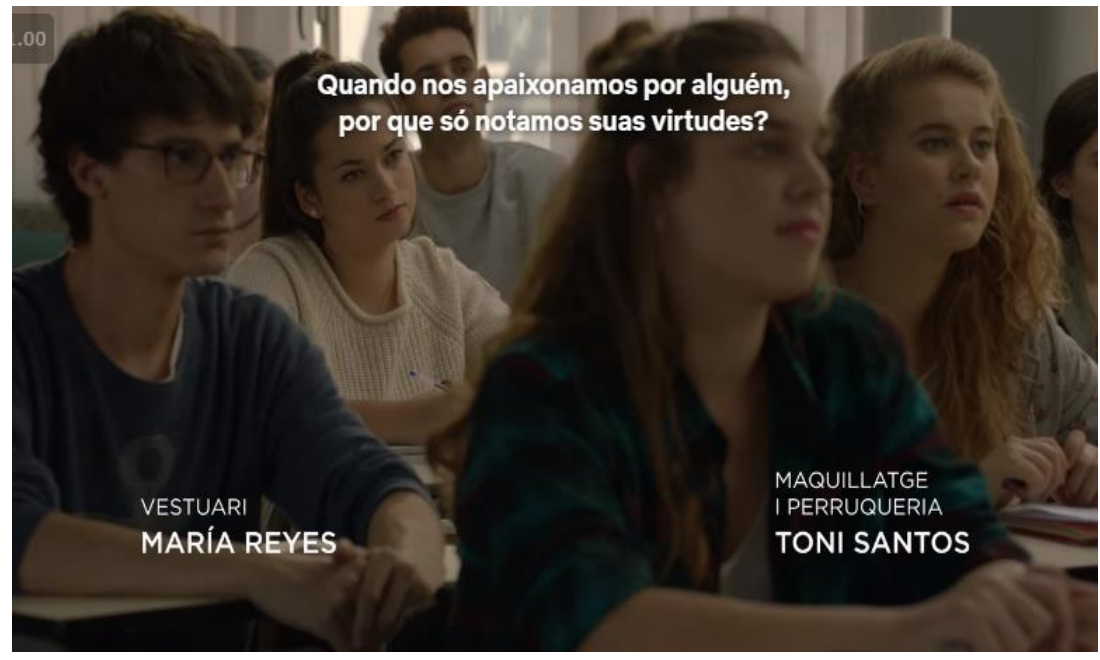

Fonte: Netflix, 2020

Na Figura 3, presenciamos a aula sobre Zizek e o dialogismo entre Merlí e seus "peripatéticos”. O professor enuncia o conteúdo por indagações (eu para o outro) de acordo com o seu próprio conhecimento (eu para mim) e os alunos respondem de acordo com suas próprias experiências (o outro para mim), ocorrendo vários dialogismos no decorrer do episódio, diálogos carregados de bagagens de conhecimentos e vivências, que representam experiências pessoais e coletivas. É neste movimento que nos deparamos com a alteridade. Tema do próximo subtópico.

\section{Alteridade}

Se o enunciado é o discurso carregado com as particularidades individuais e o dialogismo é a troca de enunciados, podendo ocorrer internamente ou em grupo, a alteridade se embasa justamente nessa relação eu-outro, necessitando de mais de um indivíduo. Ela só existe se houver o outro, pelo fato de a alteridade estar relacionada com a resposta que é esperada pelo enunciador.

Existem duas categorias essenciais em Bakhtin: Alteridade e Dialogismo. Uma é que, quando escrevemos, temos no horizonte um interlocutor, digo o que construí e o outro entende e pode fazer outra construção em cima disso e me retornar. No outro processo, o de dialogia, os sujeitos do diálogo alteram-se em processo. O Diálogo é uma corrente inserida na cadeia infinita de enunciados (atos) em que a dúvida leva a outro ato e este a outro, infinitamente (DI CAMARGO, 2020a, p. 5657). 
Quando há dialogismo entre dois ou mais enunciadores, a alteridade se faz presente, no sentido de haver a troca de informações, valores e experiências entre os envolvidos. A alteridade seria a relação dialógica entre aqueles que discursam. No processo discursivo esperamos uma resposta daquele com quem estamos conversando, divergente ou convergente ao nosso enunciado.

Percebemos que, no pensamento de Bakhtin e de seu Círculo, a alteridade permuta a ideia de que o sujeito se constitui na e pela linguagem. Sendo assim, o diálogo se configura como um momento em que a relação eu-tu se fortalece, repercutindo as marcas sócio-históricas que os constituem nessa teia dialógica, formada pelas suas próprias vozes e de seus outros. (MORETTO; SILVA; WITTKE, 2019, p. 77).

A alteridade sempre envolverá mais de um indivíduo para que haja a troca de relações contrastantes, de distinção de pensamentos e opiniões, uma vez que o ser humano é social e interage, sendo interdependente do outro. No trecho retratado pela Figura 3 acima, percebemos que nem todos os alunos concordam com o professor. Este mostra que Zizek aponta que "devemos amar o lixo do outro", aceita-lo com todos os seus defeitos. O semblante de Oksana é visivelmente triste por Gerard não aceitar seu filho. Vemos a alteridade tanto na mensagem de Zizek, amar o outro com suas imperfeições, como na relação entre as personagens citadas.

Nesta dinâmica do dialogismo - teia dialógica - percebemos a alteridade (relação entre indivíduos), na qual estão representações das diferenças entre as personagens, o que nos permite distingui-las. Nas teias dialógicas, portanto, estão os pluralismos de vozes, representando múltiplas ideias, que constituem a polifonia dos discursos. Polifonia é o conceito que discutimos a seguir.

\section{Polifonia}

Quando Bakhtin faz referência à polifonia, aponta para o pluralismo de vozes que não necessariamente se fundem em uma consciência única, mas na dinâmica do dialogismo: "polifonia [...] indica a presença de novos e múltiplos pontos de vista de vozes autônomas, que não são submetidas a um centro. As vozes são equipolentes, ou seja, elas coexistem, interagem em igualdade de posição" (FIORIN, 2006, p. 79).

Cada indivíduo tem suas próprias particularidades, está inserido em um meio com características que o afetarão em sua jornada de vida e influenciarão em seu discurso. Quando dois ou mais seres humanos trocam enunciados e começam a dialogizar entre si, surge um discurso polifônico - discurso com pontos de vista e percepções diferentes.

Para Bakhtin, "Um mundo polifônico seria um mundo em que o pluralismo de ideias fosse efetivamente respeitado, porque todas as vozes seriam equipolentes, nenhuma voz social se imporia como a palavra última e definitiva" (Ibid., p. 83). Podemos depreender que "a unidade do texto pode ter uma 
harmonia das vozes (polifonia) ou o apagamento das vozes discordantes (monofonia)" (SOUZA; DI CAMARGO, 2019, p. 31), ou seja, enquanto houver o dialogismo polifônico, haverá respeito pela diversidade de opiniões, sem que haja imposição de um único enunciado.

Trabalhar um seriado em sala de aula por si só é um ato polifônico:

A inclusão de imagens no trabalho pedagógico, sob a perspectiva da polifonia, possibilita que esses textos sejam compreendidos como expressões da cultura, numa abordagem em que múltiplas interpretações são possíveis e muitos grupos socioculturais podem ser representados por meio de suas produções (DI CAMARGO, 2020a, p.118).

No decorrer do episódio que escolhemos como objeto de nossa análise, percebemos a polifonia nos vários discursos abordados: Bruno que quer morar em outro país, Oksana que é mãe solteira, Marc que se sente responsável pelo irmão mais novo. Cada um desses núcleos é abordado por meio de enunciações e polifonicamente, assim como no diálogo sobre fé de Ivan (Pau Poch) e Oliver (Iñaki Mur), representado na Figura 4.

Figura 4: Polifonia sobre Fé.

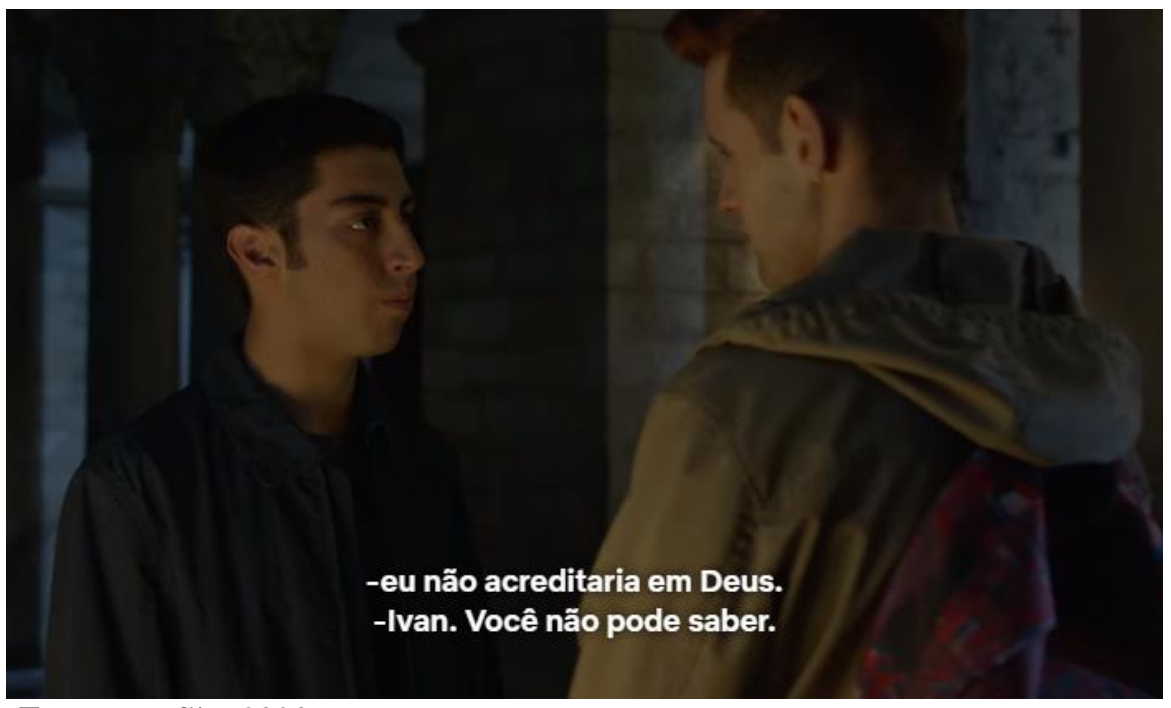

Fonte: Netflix, 2020

Quando as personagens conversam sobre fé, dentro da Igreja (Figura 4), o discurso é polifônico, uma vez que temos dois indivíduos dialogando e com pensamentos que divergem sobre questões de suas experiências e subjetividades. Um é homossexual e de muita fé (inclusive é questionado se a Igreja o aceita mesmo com sua opção sexual), Já o outro, pelo enunciado, percebemos que não tem fé em Deus. A polifonia, assim, é esse encontro de enunciados, de vozes.

No sentido dessa troca dialógica de experiências e emoções, respeitando-se as vozes que se inserem polifonicamente, "Mikhail Bakhtin considera a polifonia como um jogo de falas em um encontro entre diversos e diferentes campos emocional e volitivos" (DI CAMARGO, 2020b, p. 80). Em cenários 
polifônicos, podemos perceber uma série de figuras de linguagens que representam a diversidade de sentidos que há na alteridade, muitos deles dotados de irreverencias análogas às alegorias carnavalescas.

Neste contexto, como discutimos a seguir, Bakhtin caracteriza o carnavalesco como um processo libertário na teia dialógica, no qual os interlocutores utilizam do 'riso' e do 'humor' como formas de intervenções discursivas, muitas vezes, como contravenção.

\section{Carnavalesco}

O tópico carnavalesco abrange muito mais do que um período anual comemorativo: “O carnaval de que trata Bakhtin é um espetáculo muito diferente do carnaval de nossos dias [...], não é uma festa que se presencia, mas que se vive. [...] Questiona-se ludicamente todas as normas” (FIORIN, 2006, p. 92). A linguagem carnavalesca é a linguagem do riso, do cômico, como também da sátira, pois o enunciado é envolto em um manto de críticas sociais e políticas. "A linguagem carnavalesca é familiar, repleta de sarcasmos e insultos. No entanto, esses xingamentos e zombarias não têm um caráter ofensivo, mas brincalhão" (Ididem, p. 94), como vemos em sátiras, em que "a comicidade encontra-se na correlação entre natureza física e espiritual, sendo que a primeira põe à mostra os defeitos do segundo, logo o corpo humano pode se tornar ridículo, constituindo o objeto risível” (PROPP apud DI CAMARGO, 2020b, p. 247).

Assim, para Bakhtin o gênero paródia é de natureza carnavalesca, por tratar de assuntos sérios, mas de forma zombeteira, um sarcasmo que almeja o riso. "Para Bakhtin, quando mostramos a nossa risada coletiva contrária a seriedade, de forma solene e repressora das noções estabilizadas pelos culturais padrões e do domínio clerical, percebe-se a relevância do riso no carnaval ou em situações carnavalescas” (DI CAMARGO, 2020b, p. 246).

Figura 5: Marc leva Pau ao trabalho da mãe.

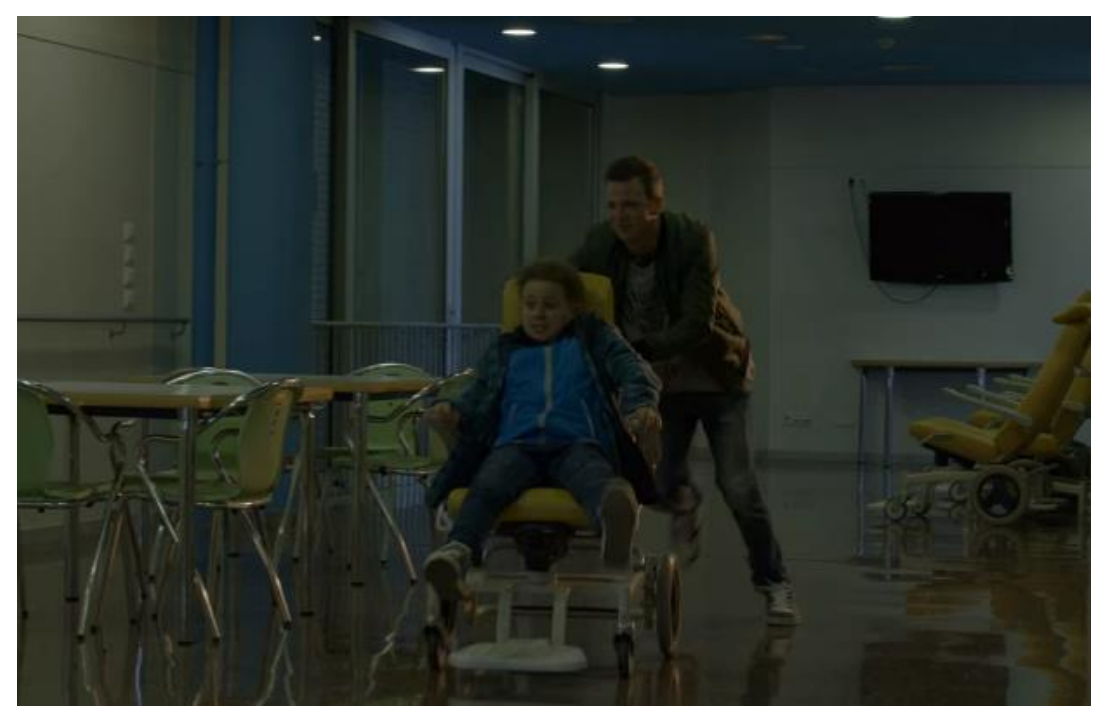

Fonte: Netflix, 2020 
Ao ver seu irmão doente e a falta de cuidados da mãe, mesmo esta sendo enfermeira, Marc resolve leva-lo ao hospital em que Lídia trabalha (Figura 5). Com leveza e em tom de brincadeira, correndo pelos corredores na cadeira de rodas e chamando a atenção de todos, o jovem mostra para a mãe que não importa ganhar mais, mas o tempo que ela passa com eles, a ausência dela é sentida por ambos os filhos.

No conceito de carnavalesco, associamos questões sociais e humanas a figuras de humor, chamando a atenção para movimentos da linguagem na produção discursiva. Isso nos remete aos conceitos de discursos centrífugos e centrípetos concebidos por Bakhtin. Tema da próxima seção.

\section{Discurso Centrífugo e Centrípeto}

Se centrífugo é aquilo que se move em direção oposta ao eixo de rotação, centrípeto busca se aproximar deste eixo. Em simples descrição, centrífugo é a fuga e centrípeto a aproximação. Bakhtin emprega esses termos no discurso - centrífugo e centrípeto. Aquele de caráter polifônico, este mais autoritário: “O sujeito bakhtiniano não está completamente assujeitado aos discursos sociais [...]. A utopia bakhtiniana é poder resistir a todo processo centrípeto e centralizador [...]. Busca-se explicar os fatos sociais por leis similares às que regem os fenômenos naturais" (FIORIN, 2006, p. 28) [grifo nosso].

O discurso centrípeto é "a aproximação ao eixo", coloca o discurso centralizado na figura autoritária que enuncia e tem voz de poder. "É aquela a que se adere de modo incondicional, que é assimilada como uma massa compacta e, por isso, é centrípeta, impermeável, resistente a impregnar-se de outras vozes, a relativizar-se. Pode ser a voz da Igreja, do Partido, do grupo de que se participa, etc.” (Ibid., p. 56). O discurso não é questionado, é imposto como verdade absoluta.

Em lado oposto, temos o discurso centrífugo que, como um ventilador, lança os enunciados para todos os lados, correndo em direção contrária ao eixo, espalhando-se. "Outras vozes são assimiladas como posições de sentido internamente persuasivas. São vistas como uma entre outras, por isso, são centrífugas, permeáveis à impregnação por outras vozes, à hibridização, e abrem-se incessantemente à mudança (Ibid., p. 56). Os discursos centrífugos fogem do autoritarismo centrípeto, não há uma verdade absoluta, mas as verdades que cada indivíduo carrega consigo, de acordo com suas vivências e práticas sociais.

Aqui duas categorias bakhtinianas dialogizam entre si - discurso centrífugo e carnavalesco: “Ao esforço centrípeto dos discursos de autoridade opõe-se o riso, que leva a uma aguda percepção da existência discursiva centrífuga" (FIORIN, 2006, p. 89). O carnavalesco busca, como visto no tópico anterior, ironizar o enunciado autoritário, de forma cômica e, por meio do riso, satirizar problemas sociais, econômicos, políticos, etc.

Percebemos esses dois discursos presentes no diálogo, entre Marc e sua mãe. Lídia quer impor sua autoridade de mãe (discurso centrípeto), trabalhar noturnamente e se divertir durante o dia, jogando a responsabilidade e cuidados do filho mais novo ao primogênito. Marc se sente pressionado pela 
responsabilidade de cuidar do irmão mais novo e tenta convencer a mãe de sua ausência (discurso centrífugo). Também temos esse movimento quando Merlí, doente e sem poder ir à escola, sai do convencional e resolve lecionar de casa, pelo computador (Figura 6).

Figura 6: Merlí leciona de casa.

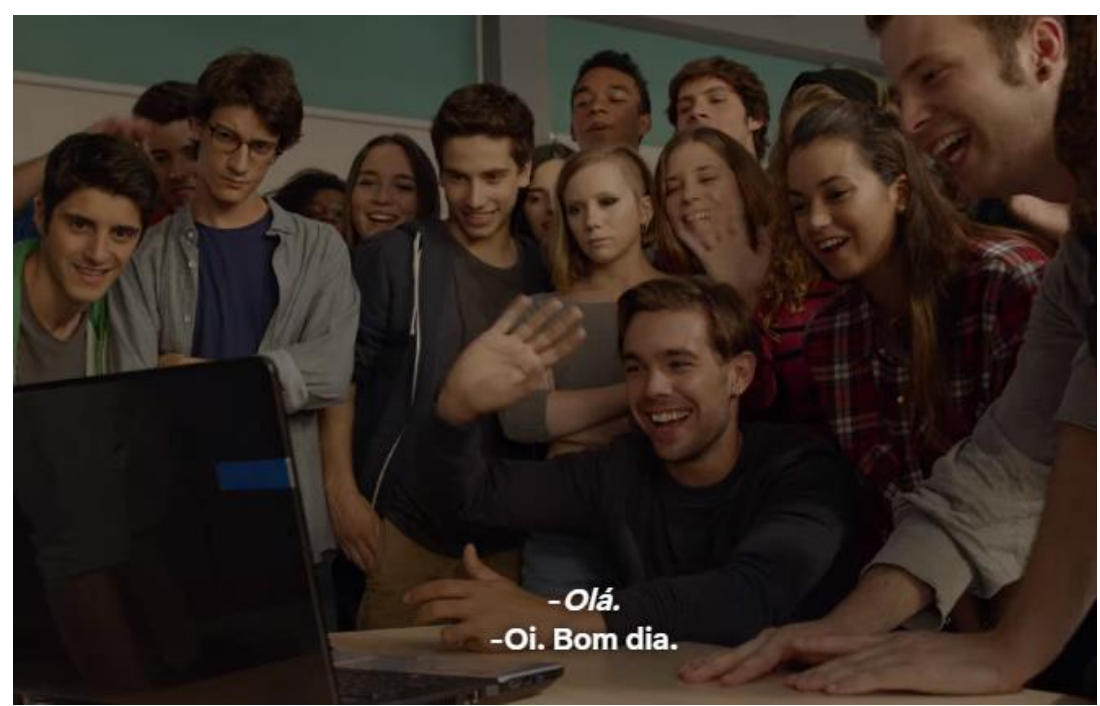

Fonte: Netflix, 2020

O professor pede que seu filho faça a conexão mediática, ligando o equipamento, e continua sua aula sobre Zizek. O discurso centrípeto revela-se no próprio movimento da sala que se converge para ouvir o professor pela mediação digital, denotando aí, a sua autoridade. Esta está ratificado pelo verbo no tom imperativo que Merlí utiliza no início da aula. "Amanhã eu voltarei para a escola. Ainda estou me recuperando. Mas hoje, darei aula de casa gralhas à tecnologia”. Embora os alunos parecem concordar com a situação, em momento algum o professor lhes questiona se aquele formato de aula será pertinente, impondo o modelo.

Por sua vez, nesta mesma cena temos a presença do discurso centrífugo. Primeiro há uma ruptura com o padrão didático imposto pela escola, o que representa uma fuga à tradição. Isso gerou uma nova abordagem realizada pelo professor, que está presente na sala de forma virtual, utilizando trajes de dormir e se descolocando pela cozinha de sua residência. Os alunos estavam na sala de aula e o professor também, mas não de formas convencionais.

A cena estabelece uma relação entre ambiências sociais e digitais, característica da atual cibercultura. Tal experiência indica a temporalidade do discurso, o que iremos apresentar a seguir, 


\section{Cronotopo}

Para se compreender a categoria cronotopo, indicada por Bakhtin, há que se levar em consideração que tudo o que o indivíduo vive está envolto em um cenário e época. O cronotopo seria mais do que o tempo e o lugar que um fato se passa, engloba todas as experiências vividas nesse contexto:

A relação entre espaço e tempo é indissolúvel. O cronotopo é uma categoria conteudística-formal, que mostra a interligação fundamental das relações espaciais e temporais representadas nos textos, principalmente literários. [...] Figura-se o mundo por meio de cronotopos, que são, pois, uma ligação entre o mundo real e o mundo representado, que estão em interação mútua (FIORIN, 2006, p. 134).

Dessa forma, todo enunciado, real ou fictício, é abraçado por um cronotopo: hora, dia, mês, ano, cidade, estado, país, características culturais, sociais, políticas, religiosas.

O sujeito de Mikhail Bakhtin, por estar situado no tempo e no espaço é um sujeito em constante movimento. Isso significa afirmar que ele sempre será um ser inacabado, pois o gênero sempre será algo novo. [...] A sua cronotopia, lugar único e intransferível na relação de espaço e tempo, vai determinar a renovação de cada sentido" (DI CAMARGO, 2020b, p. 188).

Assim, o cronotopo do seriado se divide nas três séries do Ensino Médio (cada temporada), começando no ano de 2016, tem como cenário uma escola pública da Catalunha, na Espanha. Além da escola, outros cenários são apresentados, como passeios escolares e as casas dos estudantes e do professor. E, dentro desses cenários, vivenciamos junto com cada episódio, as alegrias, frustrações, dilemas, tristezas, de cada personagem.

O Cronotopo não se resume ao pano de fundo, mas a todo o cenário em que se passa a série, não apenas fisicamente (escola e casas), mas todas as experiências vivenciadas pelas personagens, além de indicativos de períodos históricos, como as tecnologias digitais que apontam para a cibercultura. Esta temporalidade, por sua vez, não implica a exclusão do passado em um discurso. Afinal são as memórias que possibilitam a continuidade das ações e definem suas singularidades. O que mostramos próxima seção.

\section{Exotopia}

Se o cronotopo é o pano de fundo das experiências, o ato de externalizar os fatos passados é denominado por Bakhtin como exotopia: “As memórias são a possibilidade de cada sujeito existir como singular e este conceito Bakhtin nos apresentou como exotopia” (DI CAMARGO, 2020b, p. 195), um excedente de visão.

A "palmatória" (castigo empregado pelo professor) era admissível nas escolas brasileiras até a década de 1970, transformando-se em crime na década de 1980. Hodiernamente, é um ato inadmissível e inescrupuloso o uso da palmatória, mas, para quem viveu naquela época, o castigo faz parte de suas memórias e relembrar é a exotopia, revisitar o palácio das lembranças - boas ou ruins. 
Então na exotopia há a externalização dos enunciados, carregados com a experiência que foi vivenciado em algum espaço e tempo, carregado de simbolismos para quem transmite e de aprendizagens para quem recebe. É o que acontece quando Oksana decide terminar o relacionamento com Gerard. Ela conta que ao nascer foi entregue a adoção pela mãe, que tinha apenas 18 anos, demostrando não querer reproduzir a situação com seu filho.

“O princípio da exotopia pode ser observado na relação criadora como um estar-fora. [...] Podemos verificar também no conceito de exotopia a implicação de uma preocupação a respeito da ideia de espaço e de tempo" (DI CAMARGO, 2020b, p. 87-88). Assim, a própria estrutura da série parte do princípio da exotopia. Afinal, cada episódio inicia com uma "exotopia" do capítulo anterior, uma recapitulação dos principais acontecimentos que marcaram as personagens, uma forma de "recordação" do que foi abordado anteriormente, para atualizar o espectador.

$\mathrm{Na}$ totalidade da narrativa do seriado, este processo funciona como uma memória do passado. O que abordaremos a seguir.

\section{Memória de passado}

Memória não é pensar no que já passou, como nos mostra Bakhtin. Temos a memória de passado, ao relembrar algo já ocorrido e que fazemos referências passadas, e a memória de futuro, quando projetamos nossos anseios e desejos naquilo que ainda está por vir. $\mathrm{O}$ que propõe que as memórias correspondem a narrativas sobre experiências individuais e/ou coletivas.

Quando Bakhtin fala da memória, ele explica que a memória é sempre de passado e de futuro. Elas andam juntas, são complementares. Os sujeitos estão inseridos na História e em seus valores. Ao enunciar, resgatam-se esses valores já estabelecidos, mas ao invocar os valores ou significações, imediatamente se reinventa o sentido, pois o indivíduo contribuiu com o tom, com a expressão, com o desejo do que quer dizer. A memória do passado é o que se pode chamar de atual, contemporâneo; já a memória de futuro é o utópico, isto é, ainda sem lugar, ainda não concretizado. A primeira tem a ver com a estética, pois a constituição do indivíduo (DI CAMARGO, 2020a, p. 99-100).

Na memória está um conjunto de percepções, experiências, formações cognitivas e projeções de futuro dos interlocutores de um discurso. Todas as lembranças do que já foi vivido constitui a memória de passando. Todas as projeções e planos representam a memória de futuro. Com uma gripe que o deixa acamado, Merlí recebe os cuidados da mãe (Figura 7), Carmina Calduch (Ana María Barbany), e relembra a fala de uma peça que a ajudou a decorar. Essa memória de passado está presente também quando a mãe de Gerard, Gina Castells (Marta Marco), recebe Oksana e seu filho para um café e relembra a infância do próprio filho. 
Figura 7: Merlí recorda uma apresentação de sua mãe.

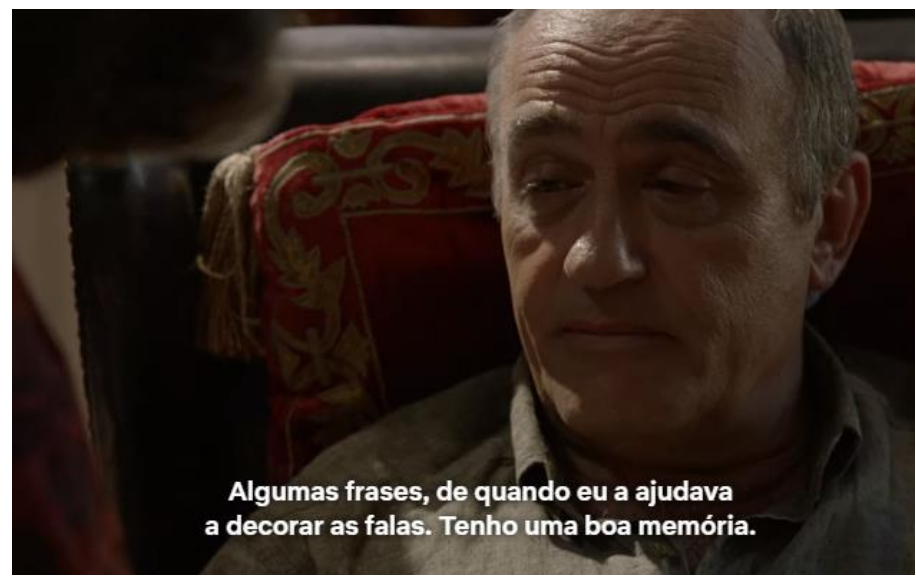

Fonte: Netflix, 2020

Como exemplo de memória de futuro, temos a cena em que Merlí chama seu filho, Bruno, para conversar sobre sua viagem para Roma. O pai não quer que o filho viaje brigado com ele, e os dois falam sobre o futuro. Em seguida, na cena em que Bruno está acamado, ele confessa ao pai suas perspectivas em relação à vida que terá em Roma apontando para ânsias e temores. Assim, nas memórias estão representações das experiências individuais e coletivas que apontam para diversidades e contradições das histórias. É o que Bakhtin entende como refração. A nossa próxima categoria de análise.

\section{Refração}

$\mathrm{Na}$ Física, refração é a mudança na velocidade de uma onda ao atravessar a fronteira entre dois meios com diferentes índices de refração. Uma experiência fácil para se compreender o conceito é a seguinte: coloque água em um copo e posicione um papel com uma seta por trás, perceberá que a seta ficará invertida por conta da refração da água.

Para Bakhtin, "a refração é o modo como se inscrevem nos signos a diversidade e as contradições das experiências históricas dos grupos humanos" (FARACO, 2009, p. 51). Assim, refratamos os acontecimentos diários, de acordo com nossas próprias perspectivas e experiências. "As mudanças na vida cotidiana são mais rápidas e produzem reflexo nas esferas imediatamente superiores à nossa vida cotidiana de maneira mais efetiva. Essas mudanças são as que movimentam o mundo para outros lugares" (SOUZA; DI CAMARGO, 2019, p. 9).

Conforme o que foi exposto, a refração é a interpretação pessoal que o indivíduo tem do enunciado exposto. Como a água que refrata contrariamente a seta, tendemos a colocar nosso ponto de vista e percepção na nossa resposta ao que nos foi transmitido. Refratamos, interpretamos, os enunciados que recebemos de acordo com nossa capacidade de análise e pensamento crítico: 
É nesse sentido que os textos do Círculo vão dizer recorrentemente, que os signos não apenas refletem o mundo (não são apenas um decalque do mundo); os signos também (e principalmente) refratam o mundo. Em outras palavras, o Círculo assume que o processo de transmutação do mundo em matéria significante se dá sempre atravessado pela refração dos quadros axiológicos. [...] Quer dizer: com os signos podemos apontar para uma realidade que lhes é externa (para a materialidade do mundo), mas o fazemos sempre de modo refratado. E refratar significa, aqui, que com nossos signos nós não somente descrevemos o mundo, mas construímos [...] diversas interpretações (refrações) desse mundo (FARACO, 2009, p. 50-51).

Quando Oksana compartilha sua vida com Gerard, deixando que este participe do cotidiano do filho, ela espera proatividade e companheirismo, mas não é o que Gerard "refrata" da situação (Figura 8), sentindo-se pressionado em assumir ainda na adolescência um filho que não é seu e sendo motivo de piadinhas entre os amigos.

Figura 8: Confronto entre Oksana e Gerard.

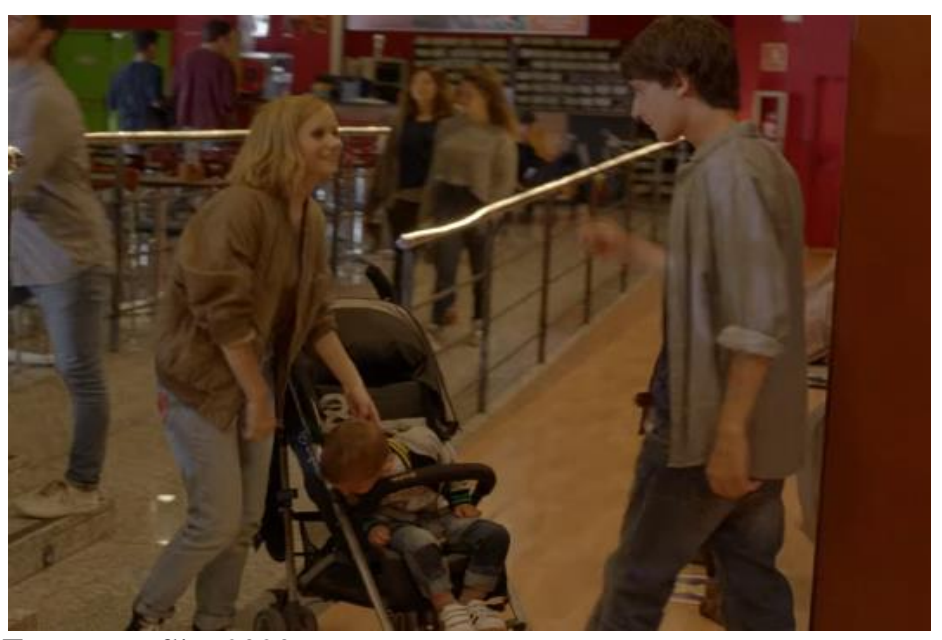

Fonte: Netflix, 2020

A forma como Gerard age em todo o episódio "refrata" como ele se sente em relação ao contexto de sua relação com a garota. Ele quer curtir, se divertir com Oksana, mas sem as responsabilidades de "pai". Ela não aguenta o comportamento e rompe a relação. Temos também o trecho em que Tânia (Elisabet Casanovas) refrata as atitudes de Pol (Carlos Cuevas) de modo agressivo, quando este não tem cuidado com as palavras e a magoa.

\section{Considerações}

Depreendemos que a complexidade dos conceitos bakhtinianos está no fato da relação que eles têm uns com os outros, complexo no sentido de suas relações serem interdependentes e de seus componentes por vezes se mesclarem, causando confusão em alguns. Estudá-los separadamente é apenas uma forma de abordagem, mas não exime o caráter conectivo entre eles. O dialogismo é formado por enunciados e está envolto em um cronotopo, pertencendo a um discurso que podes oscilar em centrífugo e centrípeto, por 
exemplo. Neste movimento do discurso podemos identificar alteridade, memorias, refrações e até figuras carnavalescas.

Quando abordamos estes conceitos separadamente, não pretendemos simplificar, mas clarear as dúvidas mais frequentes. Ao correlacionarmos com o seriado Merlí, possibilitamos que o conteúdo seja facilmente relacionado com vivências pessoais. Ao apontarmos que determinado conceito é perceptível em tal trecho, deixamos a brecha para que o espectador veja sua empregabilidade em alguma experiência pessoal.

Nossa proposta é que leigos e iniciantes na jornada bakhtiniana possam se beneficiar do presente estudo como um primeiro passo e buscar aprofundar-se ainda mais com suas próprias pesquisas. A fundamentação conceitual aqui é trazida em uma linguagem clara e direta, direcionando-os àquele primeiro contato ou para sanar possíveis dúvidas. Uma vez provado o "sabor dialógico", a sede é insaciável e a busca infindável.

\section{Agradecimentos}

Não poderíamos deixar de externar nossa gratidão ao Grupo de Estudos "O círculo de Bakhtin em diálogo", UEPB/DGP/CNPq. Esta produção é nossa pequena contribuição aos muitos estudos já realizados em torno desta ilustre figura que nos entrega um universo de possibilidades de dialogismo entre o eu, o outro e o nós. Uma vez imerso neste mar dialógico, não há como se manter o mesmo olhar, a mesma perspectiva, tudo é "bakhtiniano".

\section{Referências}

DI CAMARGO, Ivo Júnior. A memória de futuro em tela: diálogos entre cinema e Bakhtin. São Paulo: Mentes Abertas, 2020a.

DI CAMARGO, Ivo Junior. Mikhail Bakhtin na linguagem cinematográfica. São Paulo, Mentes Abertas, 2020b.

FARACO, Carlos Alberto. Linguagem \& diálogo: as ideias linguísticas do círculo de Bakhtin. São Paulo: Parábola Editorial, 2009.

FIORIN, José Luiz. Introdução ao Pensamento de Bakhtin. São Paul: Ática, 2006.

Martins, Gilberto de Andrade. Manual para elaboração de monografias e dissertações. 2 ed. São Paulo: Atlas, 1994.

MORETTO, M.; SILVA, A. P.; WITTKE, C. I. A importância da alteridade para a apropriação da leitura e escrita: o outro revelado nos memoriais de formação. In: MORAES, A. M.; MORETTO, M.; SILVA, R. C. A. (Orgs.). Bakhtin em diálogo: vozes brasileiras em ação. São Paulo: Mentes Abertas, 2019. SOUZA, Fábio Marques; DI CAMARGO, Ivo Júnior (Org.). O Círculo de Bakhtin em diálogo: relatos de pesquisas. São Paulo: Mentes Abertas, 2019.

SOUZA, Fábio Marques de; SOARES, Maxwell Barboza. Confluências entre cinema e educação: reflexões mediadas por Darcy Ribeiro, Mikhail Bakhtin e Paulo Freire. São Paulo, Mentes Abertas, 2020. 